University of Nebraska - Lincoln

DigitalCommons@University of Nebraska - Lincoln

6-2009

\title{
Alternative Life Cycle Strategies and Colonization of Young Anurans by Gorgoderina attenuata in Nebraska
}

\author{
Matthew G. Bolek \\ Oklahoma State University, bolek@okstate.edu \\ Scott D. Snyder \\ University of Nebraska at Omaha, sdsnyder@mail.unomaha.edu \\ John J. Janovy Jr. \\ University of Nebraska - Lincoln, jjanovy1@unl.edu
}

Follow this and additional works at: https://digitalcommons.unl.edu/bioscijanovy

Part of the Parasitology Commons

Bolek, Matthew G.; Snyder, Scott D.; and Janovy, John J. Jr., "Alternative Life Cycle Strategies and Colonization of Young Anurans by Gorgoderina attenuata in Nebraska" (2009). John Janovy Publications. 64.

https://digitalcommons.unl.edu/bioscijanovy/64

This Article is brought to you for free and open access by the Papers in the Biological Sciences at DigitalCommons@University of Nebraska - Lincoln. It has been accepted for inclusion in John Janovy Publications by an authorized administrator of DigitalCommons@University of Nebraska - Lincoln. 


\title{
ALTERNATIVE LIFE CYCLE STRATEGIES AND COLONIZATION OF YOUNG ANURANS BY GORGODERINA ATTENUATA IN NEBRASKA
}

\author{
Matthew G. Bolek*, Scott D. Snyder†, and John Janovy, Jr.ł \\ School of Biological Sciences, University of Nebraska-Lincoln, Lincoln, Nebraska 68588. e-mail: bolek@okstate.edu
}

\begin{abstract}
Studies on life cycles and epizootiology of North American frog bladder flukes indicate that adult frogs become infected predominantly by ingesting tadpoles or other frogs that serve as second intermediate hosts for gorgoderid metacercariae. Other studies have indicated that newly metamorphosed frogs are rarely infected with these parasites because they are gapelimited predators that cannot feed on large intermediate hosts such as tadpoles and other frogs. We examined the role of potential intermediate hosts in the recruitment of the frog bladder fluke, Gorgoderina attenuata, to metamorphosed northern leopard frogs, Woodhouse's toads, and bullfrogs from western Nebraska. We completed the life cycle of G. attenuata in the laboratory in 3 anuran species by experimentally infecting a variety of hosts. In addition, we generated and compared DNA sequence data from life cycle stages collected from a variety of naturally infected hosts. Our field and laboratory data indicate that in Nebraska $G$. attenuata has a truncated, 2-host life cycle that includes fingernail clams and anurans. Cercariae are ingested directly by tadpoles; unencysted juvenile worms then develop in the kidneys of tadpoles before moving to, and maturing in, the urinary bladder when tadpoles metamorphose. Additionally, G. attenuata can infect metamorphosed leopard frogs, bullfrogs, and toads when metacercariae in damselfly second intermediate hosts are ingested. These worms can also infect adult bullfrogs when they feed on other infected anurans possessing worms in their kidneys. Comparison of our material to published accounts of G. attenuata morphology and life cycles in Massachusetts suggests that previous work may have inadvertently involved 2 different species of gorgoderids. Our comparative approach to life cycle studies in different anuran life stages and multiple species of hosts suggests that tadpoles and metamorphosed anurans have favored alternative life cycle strategies in this trematode.
\end{abstract}

Recently there has been an increased interest in attempts to understand adaptations involved in the evolution of complex life cycles of parasitic organisms (see Poulin and Cribb, 2002; Parker et al., 2003). These studies have derived mathematical models of how complex life cycles might have evolved from simple life cycles or conducted meta-analysis from a phylogenetic perspective on life cycle variation among different genera and families of parasites. The results of these studies suggest that we need additional field and experimental data to better understand the selective pressures that have resulted in the evolution of these highly improbable complex life cycles. A major impediment of this evolutionary understanding comes from the fact that few data exist concerning different life cycle strategies among closely related parasite taxa that are distributed in different combinations of hosts in different parts of the world (see Grabda-Kazubska, 1976; Snyder and Janovy, 1994, 1996; Poulin and Cribb, 2002; Bolek and Janovy, 2007a, 2007b).

Bolek and Janovy (2007a) argued that amphibian parasites may be good model systems to address questions of parasite life cycle diversity and evolution. Recent comparative studies on amphibian parasite life cycles, recruitment, and community structure in anuran hosts by Bolek and Coggins (2000, 2001, 2003), Muzzall et al. (2001), Bolek and Janovy (2007a, 2007b, 2008), and Yoder and Coggins (2007) have provided base line data on the distribution, demography, field host specificity, and life history of amphibian parasites. These studies suggest that life cycle strategies of amphibian parasites are adapted to the environment and ecology of their hosts; however, life cycle

Received 4 August 2008; revised 26 September 2008; accepted 14 November 2008.

* Current address: Department of Zoology, Oklahoma State University, Stillwater, Oklahoma 74078.

$\dagger$ Department of Biology, University of Nebraska at Omaha, Omaha, Nebraska 68182.

$\ddagger$ School of Biological Sciences, University of Nebraska-Lincoln, Lincoln, Nebraska 68588.

DOI: $10.1645 / G E-1813.1$ strategies of congeners and individual species in different life stages of amphibians can vary substantially. This variability may provide insight into the evolution and local adaptation of complex life cycles (Grabda-Kazubska, 1976; Snyder and Janovy, 1994, 1996; Bolek and Janovy, 2007a, 2007b, 2008).

Studies on the life cycles and epizootiology of North American amphibian bladder flukes indicate a remarkable plasticity in the use of second intermediate hosts in their life cycles. North American species of Gorgodera and Gorgoderina primarily use tadpoles as second intermediate hosts but can also use odonates and molluscs. However, species of Phylodistomum use arthropods as second intermediate hosts, while adult amphibians become infected by ingesting arthropods, snails, tadpoles, or other frogs infected with metacercariae (Krull, 1935; Rankin, 1939; Crawford, 1940; Goodchild, 1943, 1948; Ubelaker and Olsen, 1972). Field studies also indicate that within individual anuran species, newly metamorphosed and juvenile anurans are less commonly infected with bladder flukes than are larger adult frogs because of small gape size, which affects the size of potential intermediate hosts that can be ingested by these frogs (see Bolek and Coggins, 2003; Bolek and Janovy, 2007a). Contrary to these studies, our observations from $\mathrm{Ne}$ braska indicate that newly metamorphosed northern leopard frogs, which never feed on tadpoles or other anurans (Bolek and Janvoy, 2007a), are commonly infected with Gorgoderina attenuata, with prevalences reaching $80 \%$.

We examined the population structure, recruitment, and route of infection of $G$. attenuata in young-of-the-year northern leopard frogs (Rana pipiens), Woodhouse's toads (Bufo woodhousii), and bullfrogs (Rana catesbeiana) from western Nebraska in order to elucidate any differences in this bladder fluke's life cycle strategy. Additionally, we compare our results to the original life cycle work on $G$. attenuata from western Massachusetts by Rankin (1939). The conceptual strength of the present study rests with the examination of alternative routes of infections by a single trematode species to 3 different anuran species 
that vary in their life histories and phylogenetic relationships (Lannoo, 2005).

\section{MATERIALS AND METHODS}

\section{Gorgoderina attenuata field studies in tadpoles and metamorphosed leopard frogs}

During July-September 2001 and July 2002, 125 newly metamorphosed northern leopard froglets were collected from Cedar Creek, Keith County, Nebraska $\left(41^{\circ} 11.194^{\prime},-101^{\circ} 21.820^{\prime}\right)$. All frogs were placed on ice as they were collected and brought into the laboratory. Frogs were killed, the snout vent length (SVL) was measured, and they were examined for bladder fluke metacercariae in the skin and viscera as well as worms in the urinary bladder within 1-6 hr of collection. Additionally, 12 northern leopard frog tadpoles (Gosner stage 39-41) collected from Cedar Creek during July 2002 were brought to the laboratory, maintained through metamorphosis in 45.5-L tanks filled with aged tap water for a period of 3-6 wk, then examined for bladder flukes.

To understand at what stage, age, or both newly metamorphosed northern leopard frogs acquired bladder fluke infections, we examined the seasonal recruitment of $G$. attenuata by collecting 60 northern leopard frog tadpoles (20 individuals every 2-3 wk during May-July 2003) and 20 metamorphosed froglets during July 2003 from Cedar Creek. All tadpoles and froglets were collected with a dip net, placed on ice, and necropsied within 1-6 $\mathrm{hr}$ of collection. They were aged and measured according to Gosner (1960) and McDiarmid and Altig (1999) and examined for gorgoderid metacercariae in the skin, musculature, an viscera, as well as for worms in the kidneys and urinary bladder. Kidneys were removed from tadpoles and froglets, pressed between 2 slides, and examined for any juvenile or encysted worms. Worms were fixed in 95\% ethanol or AFA, and representative worms were stained and permanent slides prepared. Kidneys of some tadpoles were fixed in Bouin's fixative, embedded in paraffin, sectioned at $12 \mu \mathrm{m}$, affixed to slides, stained with hematoxylin and eosin, mounted in Canada balsam, and examined microscopically.

\section{Gorgoderina attenuata field studies in 3 sympatric anuran species}

During June-September 2004, 20 tadpoles each of northern leopard frogs and Woodhouse's toads were collected from Cedar Creek, 20 bullfrog tadpoles from Breen's Flyway (a pond adjacent to Cedar Creek) $\left(41^{\circ} 10.914^{\prime},-101^{\circ} 21.654^{\prime}\right)$, along with 20 metamorph or adult northern leopard frogs, 25 metamorph Woodhouse's toads from Cedar Creek, and 10 metamorph or adult bullfrogs from Cedar Creek and Breen's Flyway, and examined for gorgoderid infections in their kidneys, urinary bladder, skin, and viscera. A chi-square test for independence was calculated to compare differences in prevalence between sympatric tadpole and metamorphosed anuran species collected during 2004. The KruskalWallis test was calculated to compare differences among mean abundance among sympatric tadpoles and metamorphosed anurans collected during 2004 because variances were heteroscedastic (Sokal and Rohlf, 1981).

\section{Arthropod survey for gorgoderid metacercariae}

To examine other potential routs of infection by G. attenuata to metamorphosed anurans, we examined 227 aquatic arthropods for gorgoderid metacercariae from Cedar Creek and Breen's Flyway. All aquatic arthropods were collected with a dip net during the summer of 20012004. These included anisopteran larvae (Anax junius, N = 16; Sympetrum occidiualis, $\mathrm{N}=4$ ); zygopteran larvae (Amphiagrion abbreviatum, $\mathrm{N}=14$; Ischnura verticalis, $\mathrm{N}=11$ ); coleopteran adults (Hydrophilidae, $\mathrm{N}=27$ ); hemipterans (Belostoma sp., $\mathrm{N}=33$ ); Ephemeroptera larvae (Callibaetis sp., $\mathrm{N}=20$; Caenis sp., $\mathrm{N}=22$ ); dipteran larvae (Stratiomyidae, $\mathrm{N}=9$ ); amphipods (Hyalella azteca, $\mathrm{N}$ $=70$ ); and decapods (Orconectes, sp. $\mathrm{N}=1$ ). Aquatic arthropods were brought to the laboratory, identified to family, genus, or species using keys in Borror et al. (1989), Merritt and Cummins (1996), Westfall and May (1996), Needham et al. (2000), and Thorp and Covich (2001), and gently teased apart for metacercariae with forceps in insect saline.

\section{Gorgoderina attenuata laboratory northern leopard frog tadpole infections}

Sphaerid pea clams (Pisidium compressum) were collected during June-July 2003 from Cedar Creek by sifting aquatic vegetation and sand in the stream with a $1-\mathrm{mm}$ mesh size strainer. Individual clams were isolated in $1.5-\mathrm{ml}$ well plates filled with aged tap water and observed daily for shedding gorgoderid cercariae. Some cercariae were fixed in AFA and representative cercariae were stained and permanent slides prepared.

Northern leopard frog tadpoles (Gosner stage 30-36) were collected from Cedar Creek during May 2003 when no apparent infections were present and maintained in the laboratory in 45.5-L tanks for $2 \mathrm{wk}$. Tadpoles were divided into 3 groups and assigned to either a time- 0 control $(\mathrm{N}=20)$, experimental $(\mathrm{N}=10)$, or time- $\mathrm{T}$ control $(\mathrm{N}=10)$ and were isolated in 5-ml well plates filled with aged tap water for 1 $\mathrm{hr}$ before exposure. Time- 0 controls were dissected at the beginning of the experimental infections, whereas time-T controls were maintained throughout the duration of the experiment and dissected along with the experimental group. Gorgoderid cercariae were isolated from the shedding clams, and 3-10 cercariae were individually provided to each experimental tadpole over a period of 1-3 days. Tadpoles were observed using a dissecting microscope until they ingested an individual cercaria before another cercaria was introduced into the $5-\mathrm{ml}$ well plate containing the tadpole. Additionally, the water in each well containing individual tadpoles was checked for any dead cercariae 12-24 hr after exposure. All infected tadpoles and time-T controls were maintained in groups of 1-4 on a diet of frozen mustard greens and Tetra Min ${ }^{\circledR}$ fish food in 45.5-L tanks. To follow infection status, bladder fluke development, and migration, experimental and time-T tadpoles were killed and necropsied 3 days to 4 wk post-exposure (Gosner stage 36-45).

\section{Gorgoderina attenuata laboratory damselfly infections}

Sphaerid pea clams were collected during June-July 2004 from Cedar Creek and processed as described previously. Ischnura verticalis damselfly larvae were collected from Dunwoody Pond, Keith County, Nebraska $\left(41^{\circ} 12.916^{\prime},-101^{\circ} 34.704^{\prime}\right)$. Larvae were divided into 3 groups and starved for 5 days before exposure; they were assigned to either a time-0 control $(\mathrm{N}=10)$, experimental $(\mathrm{N}=10)$, or time- $\mathrm{T}$ control ( $\mathrm{N}$ $=10$ ) and were isolated in $5-\mathrm{ml}$ well plates filled with aged tap water. Time-0 control damselflies were dissected at the beginning of the experimental infections; 1 to 5 cercariae were individually pipetted to each experimental damselfly larva over a period of 1-5 days. Larvae were observed using a dissecting microscope until they ingested an individual cercaria before another cercaria was introduced into the well. All exposed damselflies and time-T controls were dissected 1-6 days postexposure.

\section{Gorgoderina attenuata laboratory metamorphosed toad and bullfrog infections}

Newly metamorphosed Woodhouse's toads were collected from Beckius Pond, Keith County, Nebraska $\left(41^{\circ} 12.523^{\prime},-101^{\circ} 37.266^{\prime}\right)$ and divided into 3 groups: time-0 control $(\mathrm{N}=10)$, experimental $(\mathrm{N}=1)$, and time- $\mathrm{T}$ control $(\mathrm{N}=10)$. Laboratory-infected damselflies were dissected in insect saline (Hoar and Hickman, 1967). Time-0 control toads were dissected at the beginning of the experimental infections; 3 metacercariae were intubated into an experimental toad. The pipette was examined to confirm that no metacercariae remained. The experimental toad and the 10 time-T controls were killed 5 days post-exposure and examined for bladder flukes in the kidneys and urinary bladder.

Bullfrog tadpoles were collected at South Platte River, Paxton, Keith County, Nebraska $\left(41^{\circ} 07.600^{\prime},-101^{\circ} 34.611^{\prime}\right)$, brought to the laboratory, reared through metamorphosis, and divided into 3 groups: time- 0 control $(\mathrm{N}=10)$, experimental $(\mathrm{N}=2)$, and time- $\mathrm{T}$ control $(\mathrm{N}=10)$. Lab-reared bullfrogs were each fed 4, naturally infected, northern leopard frog tadpoles over a period of 4 days, with $0-10$ juvenile worms located in the kidneys (prevalence 55\%; mean abundance $1.4 \pm 2.2$ ), determined by dissecting 20 tadpoles. Thirteen to 18 days post-exposure, experimental bullfrogs were examined for juvenile and adult bladder flukes in the kidneys and urinary bladder and metacercariae in the tissues. Finally, a single adult northern leopard frog and a single laboratory-reared bullfrog were each fed 7 and 4 newly metamorphosed 
TABLE I. Gorgoderid specimens used in this study, their hosts, geographical origin of specimens, GenBank accession numbers, sequence length, and accession numbers for vouchers of corresponding sequences of gorgoderid specimens.

\begin{tabular}{|c|c|c|c|c|c|}
\hline Gorgoderid taxa & Stage/location & Host species & Geographic origin & $\begin{array}{l}\text { ITS GenBank no. } \\
\text { (sequence length) }\end{array}$ & Vouchers \\
\hline G. attenиata RP1WNE & Adult, bladder & R. pipiens & Cedar Creek, Keith County, Nebraska & FJ445736 (960) & HWML 49000 \\
\hline $\begin{array}{l}\text { Juvenile Gorgoderina sp. } \\
\text { RP3WNE }\end{array}$ & Juvenile, kidney & $\begin{array}{l}\text { Tadpole of } R \\
\text { pipiens }\end{array}$ & Cedar Creek, Keith County, Nebraska & FJ445738 (1,030) & HWML 49002 \\
\hline $\begin{array}{l}\text { Juvenile Gorgoderina sp. } \\
\text { BWEXCC }\end{array}$ & Juvenile, kidney & B. woodhousii & Cedar Creek, Keith County, Nebraska & FJ445739 (918) & HWML 49003 \\
\hline G. attenuata RCLNY & Adult, bladder & R. clamitans & Queechy, Columbia County, New York & FJ445741 (891) & HWML 49005 \\
\hline G. simplex RCLWI & Adult, bladder & R. clamitans & Eagle, Waukesha County, Wisconsin & FJ445742 $(1,060)$ & HWML 49006 \\
\hline G. amplicava RCWI & Adult, bladder & R. catesbeiana & $\begin{array}{l}\text { Big Muskego Lake, Waukesha County, } \\
\text { Wisconsin }\end{array}$ & FJ445743 (911) & HWML 49007 \\
\hline
\end{tabular}

Woodhouse's toads to see if they could survive after ingesting these potential toxic hosts.

\section{Other amphibian field surveys}

Because Rankin (1939) indicated that G. attenuata formed metacercaria stages in tadpoles and metamorphosed frogs in Massachusetts, we examined different species of adult anurans and/or their tadpoles from other locations for gorgoderid metacercariae stages to see if gorgoderid metacercariae occurred in anurans at other locations than Cedar Creek During May-September 2000-2006 and March-May 2007 an additional 9 species of adult anurans and/or their tadpoles were collected from 4 locations in Nebraska and Arkansas and examined for gorgoderid metacercariae in the skin, musculature, and viscera as well as juvenile worms in the kidneys and adults in the urinary bladder. These included (1) 69 adult bullfrogs and 2 adult plains leopard frogs (Rana blairi) collected from Nevens Pond, Keith County, Nebraska (41 ${ }^{\circ} 12.426^{\prime}$, $101^{\circ} 24.510^{\prime}$ ); (2) 100 plains leopard frogs, 108 bullfrogs, 100 Woodhouse's toads, 103 boreal chorus frogs (Pseudacris maculata), 56 cricket frogs (Acris crepitans), and 62 Cope's gray treefrogs (Hyla chrysoscelis) from Pawnee Lake, Lancaster County, Nebraska (4051.589', $\left.-96^{\circ} 53.468^{\prime}\right)$; (3) 53 bullfrog tadpoles and 3 bullfrogs from Elk Creek, Lancaster County, Nebraska $\left(40^{\circ} 53.145^{\prime},-96^{\circ} 50.048^{\prime}\right)$; and (4) 6 bullfrogs, 4 southern leopard frogs, (Rana sphenocephala), 1 green frog (Rana clamitans), 1 pickerel frog (Rana palustris), 1 eastern gray treefrog (Hyla versicolor), and 7 cricket frogs collected from a pond in

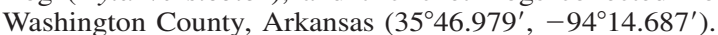

All adult gorgoderids from experimental life cycle studies and specimens collected from Arkansas, Nebraska, and other locations from North America for molecular work (see below) were identified based on the descriptions and redescriptions provided by Stafford (1902), Cort (1912), Holl (1928), Olsen, (1937), Goodchild (1950), Brooks (1976), and Bolek et al. (2009). Voucher specimens of bladder flukes have been deposited in the H. W. Manter Parasitology Collection, University of Nebraska, Lincoln, Nebraska (accession numbers HWML): 48984, G. attenuata from the urinary bladder of a northern leopard frog from Cedar Creek, Keith County, Nebraska (unless indicated otherwise, all collecting sites are in Keith County); 48985, G. attenuata from the urinary bladder of a bullfrog from Cedar Creek; 48986, G. attenuata from the urinary bladder of Woodhouse's toad from Cedar Creek; 48987, Gorgoderina sp. from the kidneys of a northern leopard frog tadpole from Cedar Creek; 48988, Gorgoderina sp. from the kidneys of a Woodhouse's toad tadpole from Cedar Creek; 48989, Gorgoderina sp. from the kidneys of a bullfrog from Breen's Flyway; 48990, $G$. attenuata from the urinary bladder of an experimentally infected northern leopard frog tadpole; 48991, Gorgoderina sp. from the kidneys of an experimentally infected northern leopard frog tadpole; 48992, G. attenuata from the urinary bladder of an experimentally infected bullfrog; 48993, G. attenuata from the urinary bladder of a bullfrog from Nevens Pond; 48994, G. attenuata from the urinary bladder of a bullfrog from Pawnee Lake, Lancaster County, Nebraska; 48995, G. attenuata from the urinary bladder of a plains leopard frog from Pawnee
Lake; 48996, G. attenuata from the urinary bladder of a bullfrog from Elk Creek, Lancaster County, Nebraska; 48997, Gorgoderina sp. from the kidney of a bullfrog tadpole from Elk Creek; 48998, G. attenuata from the urinary bladder of a southern leopard frog from a pond in Washington County, Arkansas; and 48999, gorgoderid cercaria from $P$. compressum from Cedar Creek.

\section{Specimen collection for molecular characterization}

Because the original 3-host life cycle of G. attenuata was elucidated from green frogs and other amphibian species from western Massachusetts (specific location not given) by Rankin (1939), we collected a single green frog infected with $G$. attenuata near the border of New York and Massachusetts (Queechy, Columbia County, New York; $\left.42^{\circ} 24.269^{\prime},-73^{\circ} 25.627^{\prime}\right)$ to compare the complete internal transcribed spacer region (ITS) of the ribosomal DNA (ITS 1 - 5.8S - ITS 2) of worms from the general location of the original life cycle study and worms from northern leopard frogs and Woodhouse's toads from Cedar Creek, Nebraska. Additionally, Gorgoderina simplex and Gorgodera amplicava were collected from green frogs from Eagle, Waukesha County, Wisconsin $\left(42^{\circ} 53.225^{\prime},-88^{\circ} 29.545^{\prime}\right)$ and bullfrogs from Big Muskego Lake, $\left(42^{\circ} 51.241^{\prime},-88^{\circ} 7.456^{\prime}\right)$, respectfully. These worms were collected during March-September 2003-2004 to compare the ITS sequence of $G$. attenuata to other species of amphibian gorgoderids. Living worms recovered from amphibians were allowed to release eggs in water, then thoroughly rinsed in water, identified, and fixed in $95 \%$ ethanol. A 2- to 5-mm piece of the left or right side of each single alcohol-preserved worm was then removed for DNA extraction. Once DNA was obtained, the remaining adult worm was stained and identified based on the original descriptions. Stained voucher specimens of all species were preserved. Additionally, live juvenile worms identified as Gorgoderina sp. from the kidneys of naturally and experimentally infected tadpoles or metamorphosed naturally and experimentally infected Woodhouse's toads were fixed in 95\% ethanol. Because juvenile worms from kidneys of naturally and experimentally infected tadpoles and metamorphosed anurans contained small amounts of tissue, we used the entire specimen of these individuals for DNA extraction. Species used in the analysis, hosts, collection location, sequence length, and the voucher accession number of species are listed in Table I.

\section{DNA extraction, amplification, and sequencing}

Genomic DNA was extracted from single adult worm pieces and entire juvenile worms from the kidneys of tadpoles, frogs, and toads using DNeasy tissue kits (Qiagen, Valencia, California). With the exception of a few bases at the $5^{\prime}$ and $3^{\prime}$ ends, the entire ITS rDNA (ITS $1+5.8 \mathrm{~S}+$ ITS 2) was amplified by polymerase chain reaction (PCR) using a forward primer in the $18 \mathrm{~S}$ region, Br1 (5'-GTA GGT GAA CCT GCA GAA GG), a digenean-specific reverse primer in the $28 \mathrm{~S}$ region, DigL1 (5'-GTG ATA TGC TTA AGT TCA GC), and a 58S2 (5'-TAA GCC GAC CCT CGG ACA GG) digenean-specific internal reverse primer. Reactions were performed in a $25 \mu \mathrm{l}$ total volume ac- 
cording to instructions accompanying the FildeliTaq PCR master mix kit (USB Corporation, Cleveland, Ohio). Reactions were run on a Biometra UNO under the following cycling conditions: $94 \mathrm{C}$ for $4 \mathrm{~min}$ followed by 40 cycles of $94 \mathrm{C}$ for $30 \mathrm{sec}, 50-56 \mathrm{C}$ for $30 \mathrm{sec}$, and $72 \mathrm{C}$ for $2 \mathrm{~min}$, followed by 1 cycle of $72 \mathrm{C}$ for $5 \mathrm{~min}$ for final elongation. Unincorporated PCR primers and nucleotides were removed from PCR products using High Pure PCR Purification Kit (Roche Diagnostics, Mannheim, Germany). Sequences were determined directly from PCR templates by cycle sequencing using Big Dye fluorescent dye terminators and protocols and an ABI 377 automated sequencer (Perkin-Elmer, Foster City, California). Primers used for PCR amplification were also used in sequencing reactions.

\section{Sequence analysis}

Approximately 861 to 1,060 bp were determined from the complete ITS region of the rDNA for 7 specimens representing 2 Gorgoderina species and 1 specimen of Gorgodera amplicava. Sequences were assembled using Contig Express (v. 8.0, InforMax) and provisionally aligned using ClustalX using default settings (Thompson et al., 1997) followed by alignment by eye using the Bio Edit Sequence Alignment Editor (Hall, 1999). The resultant sequence alignment was then edited by eye to remove ambiguous regions where we could not confidently identify positions of homology within these regions, and the ends of each fragment were trimmed to match the shortest sequence in the alignment yielding an 849 character alignment. Sequence divergences among and within life stages, species, and geographical location of Gorgoderina and Gorgodera were calculated using MEGA 3.1 (Kumar et al., 2004).

\section{Morphological studies for comparisons to the original life cycle of Rankin (1939)}

Morphological data were compared for the single adult $G$. attenuata drawn by Rankin (1939) in his original life cycle study to the redescription of $G$. attenuata from a variety of frogs and toads by Bolek et al. (2009). Additionally, morphological data were collected for $10 \mathrm{ju}$ venile worms from the kidneys of tadpoles, and 10 cercariae shed by pea clams used in our experimental infections. Figures were drawn of representative juvenile worms from the kidneys of tadpoles, and cercariae shed from naturally infected pea clams with the aid of a camera lucida and compared to the original description of these life cycle stages by Rankin (1939).

\section{RESULTS}

\section{Gorgoderina attenuata field studies}

Mean SVL of the 100 northern leopard froglets collected during July-September 2001 was $4.1 \pm 0.69 \mathrm{~cm}$, range 3.0$6.3 \mathrm{~cm}$, whereas the mean SVL of the 25 northern leopard froglets collected during July 2002 was $4.0 \pm 0.59 \mathrm{~cm}$, range $3.3-$ $6.5 \mathrm{~cm}$. Forty of $100(40 \%)$ froglets were infected with a single species of frog bladder fluke (G. attenuata) during 2001, with a mean abundance of $0.96 \pm 1.68$ (range $=0-10)$; whereas 19 of $25(76 \%)$ froglets were infected with G. attenuata during July 2002, with a mean abundance of $3.0 \pm 3.25$ (range $=0-$ 10). All were gravid adults located in the urinary bladder. Of the 12 northern leopard frog tadpoles collected during July 2002 and allowed to metamorphose in the laboratory, 8 of $12(66 \%)$ were infected with gravid $G$. attenuata in the urinary bladder, with a mean abundance of $2.0 \pm 2.1$ (range $=0-5$ ). No gorgoderid metacercariae were found in any of these frogs.

During 2003 no gorgoderid metacercariae were found among the 60 tadpoles (Gosner stage 32-45) or 20 newly metamorphosed northern leopard froglets $(\mathrm{SVL}=2.9 \pm 0.27$, range 2.6$3.5 \mathrm{~cm}$ ) examined during the spring and summer of 2003. Only unencysted non-gravid worms were found in the kidneys of tadpoles (Fig. 1), and non-gravid worms in the kidneys and gravid worms in the urinary bladder of froglets. Juvenile worms recovered from the kidneys of tadpoles and froglets were 428 $\pm 58 \mu \mathrm{m}$ (range 380-540) in length and $118 \pm 33 \mu \mathrm{m}$ (range 90-160) in width and contained an ovary, 2 kidney-shaped lobed vitellaria, 2 testes arranged in tandem, and a developing uterus, indicating that they are a species of Gorgoderina. Seasonally, prevalence and mean abundance ranged from a low of $0 \%$ in tadpoles to a high of $80 \%$ and $2.3 \pm 2.2$ in metamorphosed froglets. No tadpoles were infected during May 2003, with tadpoles recruiting worms in June 2003, then increasing in prevalence and abundance during July 2003 in both tadpoles and froglets (Fig. 2). Additionally, none of the newly metamorphosed leopard frogs or toads ever contained tadpoles or frogs in their stomachs.

Of the 3 species of anuran tadpoles sampled during 2004, only tadpoles of northern leopard frogs (Gosner stage 31-38) and Woodhouse's toads (Gosner stage 34-45) were infected with non-gravid Gorgoderina sp. in the kidneys, whereas none of the bullfrog tadpoles (Gosner stage 35-41) contained any worms. Mean SVL of the 20 metamorphosed northern leopard frogs collected during June-September 2004 was $4.6 \pm 1.0 \mathrm{~cm}$ and range $2.6-6.2 \mathrm{~cm}$. The mean SVL of the 25 metamorphosed Woodhouse's toads was $1.60 \pm 0.49 \mathrm{~cm}$ and range $1.0-2.8 \mathrm{~cm}$, while the mean SVL of the 10 metamorphosed and adult bullfrogs was $7.6 \pm 2.1 \mathrm{~cm}$ and range $4.5-10 \mathrm{~cm}$. All 3 species of metamorphosed and adult anurans were infected with $G$. attenuata; bullfrogs had infections in both the kidneys and the urinary bladder and the highest prevalence, mean intensity, and mean abundance of the 3 anuran species sampled (Table II). Worms from the kidneys of metamorphosed bullfrogs appeared weak and less mobile than worms in the urinary bladder; the testes and ovaries of some of these worms were irregular in shape compared to worms from the urinary bladder from all anuran species collected. Additionally, some worms recovered from the kidneys of bullfrogs were gravid. Statistically significant differences in prevalence and mean abundance of Gorgoderina sp. in the kidneys of tadpoles and G. attenuata in the kidneys and urinary bladder of frogs existed between the 3 different species of tadpoles $\left(\chi^{2}=18.07, P<0.001 ; H\right.$ corrected $=17.85, P=0.001)$ and metamorph anurans $\left(\chi^{2}=\right.$ 25.07, $P<0.001 ; H$ corrected $=31.97, P<0.001)$. None of these tadpoles, froglets, or adult frogs contained any gorgoderid metacercariae in the tissue or on the skin, and none of the metamorphosed anurans contained any tadpoles or frogs in their stomach contents.

Of the 227 aquatic arthropods examined for gorgoderid metacercariae, only odonate larvae were infected. Two of $11(18 \%)$ larval $I$. verticalis were infected with 1 metacercaria each, and 1 of $4(25 \%)$ larval Sympetrum occidiualis was infected with a single metacercaria.

\section{Gorgoderina attenuata laboratory life cycle studies}

Of the 268 sphaerid pea clams collected during 2003, 80 (30\%) shed gorgoderid cercariae (Fig. 3). Numerous field studies on parasites of fish and amphibians at Cedar Creek and other locations in Keith County, Nebraska, over the last 7 yr have indicated that only 2 gorgoderids occur at this location (Helt et al., 2003; M. Bolek, pers. obs.). The only gorgoderid known from Cedar Creek other than G. attenuata is Phyllodistomum 


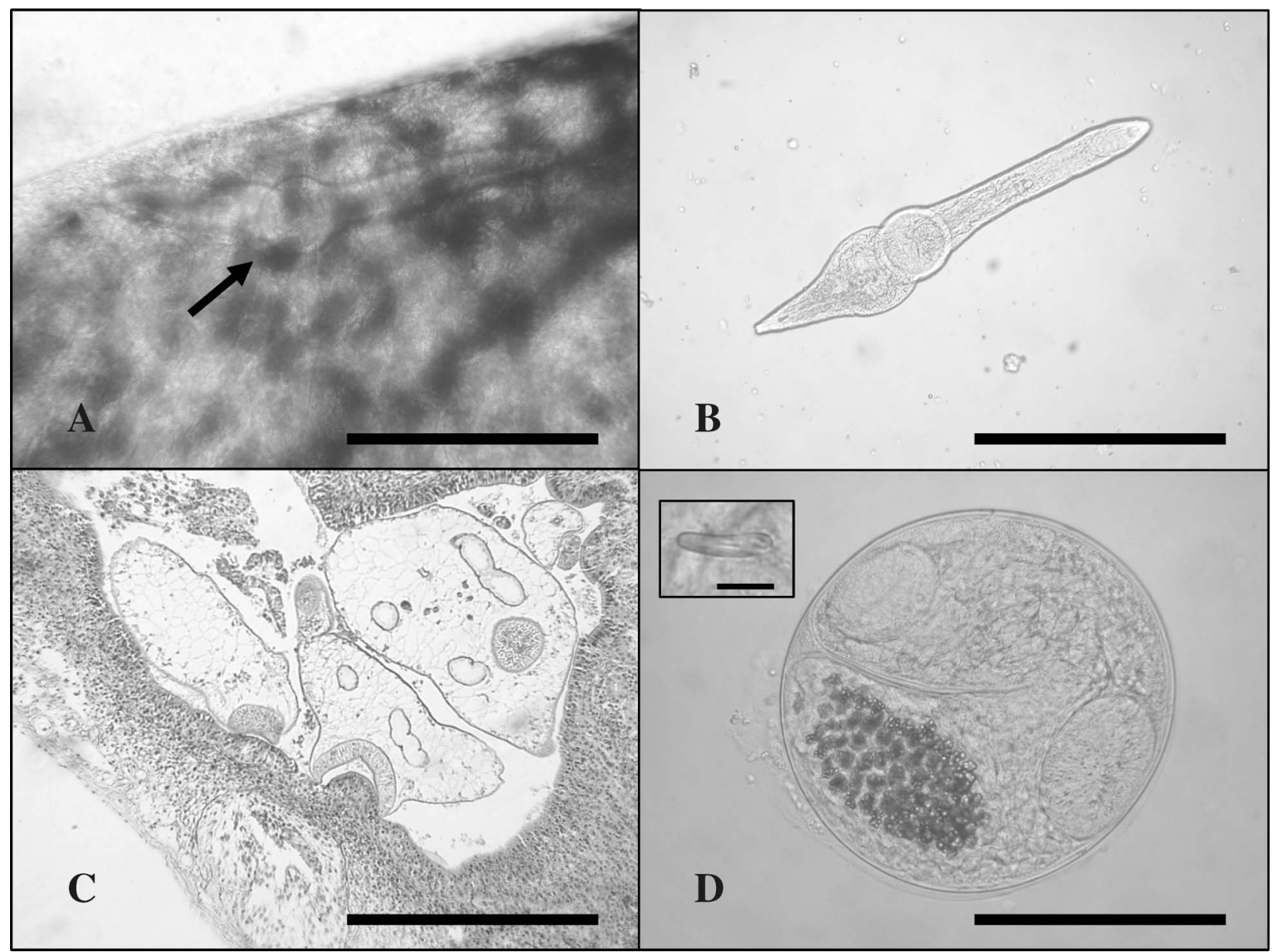

FIGURE 1. Developmental stages of Gorgoderina sp. in northern leopard frog tadpoles and the eastern forktail damselfly Ischnura verticalis. (A) Unencysted worm in a kidney of a prometamorphic northern leopard frog tadpole (arrow). Scale bar $=500 \mu \mathrm{m}$. (B) Same worm removed from the kidney. Note that the worm is not gravid. Scale bar $=500 \mu \mathrm{m}$. (C) Paraffin section through the kidney of a prometamorphic northern leopard tadpole. Note 3 unencysted non-gravid Gorgoderina sp. Scale bar $=250 \mu \mathrm{m}$. (D) Gorgoderid metacercaria recovered from a laboratoryinfected I. verticalis 6 days post-infection. Note stylet (inset). Scale bar $=100 \mu \mathrm{m} ; 10 \mu \mathrm{m}$ inset.

funduli, a bladder fluke of the plains topminnow, Fundulus sciadicus, which has a morphologically distinct cercaria (Ubelaker, 1967).

All 10 northern leopard frog tadpoles exposed to gorgoderid cercariae were observed to ingest the cercariae. Nine of 10 (90\%) experimentally exposed tadpoles became infected with what we assumed was $G$. attenuata. Additionally, 1 of $20(5 \%)$ time- 0 controls and 2 of $10(20 \%)$ time-T controls were infected with $G$. attenuata. Although both time-0 and time-T control groups were infected with 3,1 , and 1 worm, respectively, there was a statistically significant difference in the mean abundance and prevalence of $G$. attenuata among the control groups and the experimental group, indicating that our laboratory infections were successful (Kruskal-Wallis test, $H$ corrected $=23.65, P<$ $0.0001 ; \chi^{2}=23.57, P<0.001$; Fig. 4). Worms recovered from experimentally infected tadpoles 5 days post-infection (PI) were $367 \pm 30 \mu \mathrm{m}$ (range 330-410) in length and contained a developing uterus, 2 developing testes, and a developing ovary; whereas worms recovered from experimentally infected tadpoles 17 days PI were $438 \pm 28 \mu \mathrm{m}(410-469)$ in length and contained a developing uterus, 2 oval testes, an oval ovary, and
2 developing kidney-shaped lobed vitellaria. Worms recovered from the urinary bladder of metamorphosing tadpoles were identified as $G$. attenuata. All infected experimental tadpoles (Gosner stage 36-38; $\mathrm{N}=6$ ) contained 1-10 unencysted worms in the kidneys, whereas metamorphosing tadpoles (Gosner stage $44-45 ; \mathrm{N}=3$ ) contained $1-2$ worms in the urinary bladder. When all field and laboratory infection data were pooled, there was a statistically significant difference among the percent of non-gravid worms recovered from the kidneys and non-gravid and gravid worms recovered from the urinary bladder of prometamorphic tadpoles (Gosner stage 36-41), metamorphic tadpoles (Gosner stage 42-45), and metamorphosed froglets, with all worms being found in the kidneys of prometamorphic tadpoles and nearly all worms being found in the urinary bladder of metamorphic tadpoles and froglets $\left(\chi^{2}=95.4, P<0.001\right.$; Fig. 5).

Of the 150 sphaerid pea clams collected during 2004, 15 (10\%) shed gorgoderid cercariae. Damselfly larvae offered gorgoderid cercariae were immediately attracted to the beating action of the cercaria tail. In all cases the labium of the larval damselfly was projected out to grasp the cercaria, which was 

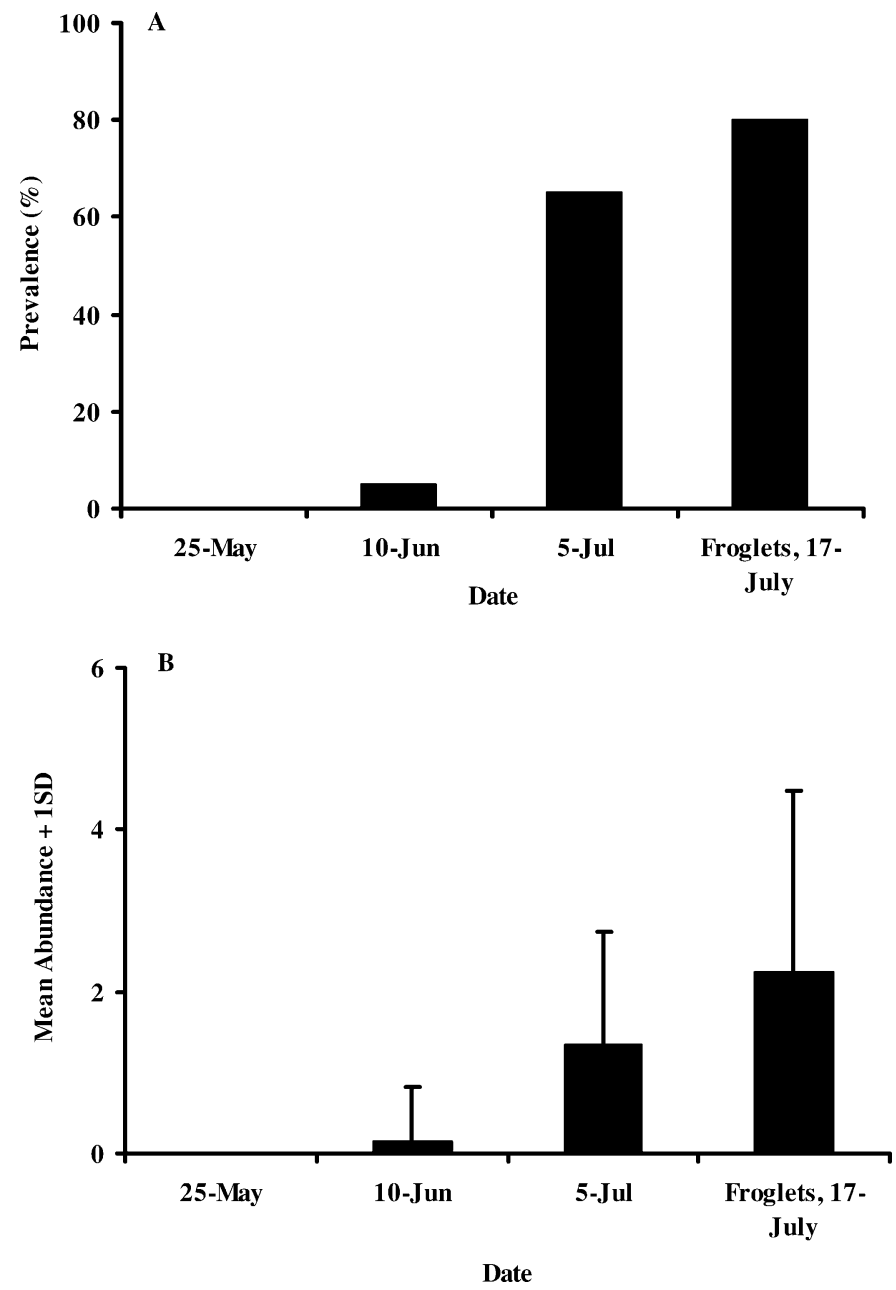

FIGURE 2. (A) Seasonal prevalence of juvenile Gorgoderina sp. in the kidneys of tadpoles and G. attenuata in the urinary bladder of 1to 2-wk-old metamorphosed northern leopard frogs collected from $\mathrm{Ce}$ dar Creek during 2003. (B) Seasonal mean abundance +1 SD of Gorgoderina sp. in the kidneys of tadpoles and G. attenuata in the urinary bladder of 1- to 2-wk-old metamorphosed northern leopard frogs collected from Cedar Creek during 2003. then ingested. After ingestion, larvae were observed rubbing their legs over the thorax followed by random thrashing and dashing through the water. Nine of $10(90 \%)$ exposed I. verticalis damselfly larvae became infected with gorgoderid metacercariae located in the heamocoel of the thorax, with a mean intensity of $3.2 \pm 1.9(1-6)$, while none of the time- 0 or time$\mathrm{T}$ controls were infected with any gorgoderid metacercariae. All metacercariae recovered from experimentally infected damselflies were encysted and resembled typical gorgoderid metacercariae (Fig. 1). Measurements of 5 metacercariae recovered 5 days PI indicated that they were $120 \pm 6.8$ (range 114-130) $\mu \mathrm{m}$ in diameter. When 3 of these metacercarie were fed to a single newly metamorphosed Woodhouse's toad and examined 5 days PI, a single juvenile worm identified a species of Gorgoderina was recovered from the kidney. None of the time- 0 or time-T control toads was infected.

The 2 laboratory-reared bullfrogs examined 13-18 days after being fed 4 naturally infected northern leopard frog tadpoles became infected with 3 and 5 G. attenuata each in the urinary bladder. Worms recovered from the urinary bladder of experimentally infected bullfrogs were $1.28 \pm 0.6 \mathrm{~mm}$ (range 0.78 2.0 ) in length, and most were gravid. None of the 10 time- 0 or 10 time-T control bullfrogs was infected with any gorgoderid life stage. The single adult northern leopard frog and single adult bullfrog each ingested 7 and 4 newly metamorphosed Woodhouse's toads and appeared to have no ill effects for $3 \mathrm{wk}$ when observations were stopped.

\section{Other amphibian field surveys}

Examination of adult anurans from 3 different locations in Nebraska and a single location in Arkansas indicated that $G$. attenuata was the only adult gorgoderid recovered. Of the 69 bullfrogs and 2 plains leopard frogs collected from Nevens Pond, only a single bullfrog $(1.4 \%)$ was infected with 1 gravid worm in the urinary bladder (mean abundance $0.01 \pm 0.1$ ). In contrast, of the 6 species of adult anurans sampled from Pawnee Lake, 6 of 100 plains leopard frogs $(6.0 \%)$ were infected with gravid worms in the urinary bladder (mean abundance of 0.08 \pm 0.3 ; range $0-2)$ and 8 of 108 bullfrogs $(7.4 \%)$ were infected with gravid worms in the urinary bladder (mean abundance of $0.15 \pm 0.7$; range $0-5$ ). Of the 6 adult anuran species sampled from a pond in Arkansas, only 1 of 4 southern leopard frogs (25\%) was infected with 3 gravid worms in the urinary bladder, with a mean abundance of $0.75 \pm 1.5$. No gorgoderid meta-

TABLE II. Prevalence (Pr), mean intensity (MI), and mean abundance (MA) of Gorgoderina sp. in tadpole and frog kidneys (Kd), and G. attenuata in the urinary bladder $(\mathrm{Bd})$ and total number of worms in the kidneys and urinary bladder (Tl) infecting metamorphs and adults of northern leopard frogs (R. pipiens), metamorphs of Woodhouse's toads (B. woodhousii), and metamorphs and adults of bullfrogs $(R$. catesbeiana) from Cedar Creek and Breen's Flyway, Keith County, Nebraska 2004.

\begin{tabular}{|c|c|c|c|c|c|c|c|c|c|c|}
\hline & \multicolumn{3}{|c|}{ R. pipiens } & \multicolumn{3}{|c|}{ B. woodhousii } & \multicolumn{4}{|c|}{ R. catesbeiana } \\
\hline & $\begin{array}{c}\text { Tadpole } \\
\mathrm{N}=20\end{array}$ & \multicolumn{2}{|c|}{$\begin{array}{c}\text { Metamorph } \\
\mathrm{N}=20\end{array}$} & \multirow{2}{*}{$\begin{array}{c}\text { Tadpole } \\
\mathrm{N}=20 \\
\mathrm{Kd}\end{array}$} & \multicolumn{2}{|c|}{$\begin{array}{c}\text { Metamorph } \\
\mathrm{N}=25\end{array}$} & \multirow{2}{*}{$\frac{\frac{\text { Tadpole }}{\mathrm{N}=20}}{\mathrm{Kd}}$} & & $\mathrm{N}=10$ & \\
\hline & $\mathrm{Kd}$ & $\mathrm{Kd}$ & $\mathrm{Bd}$ & & $\mathrm{Kd}$ & $\mathrm{Bd}$ & & $\mathrm{Kd}$ & $\mathrm{Bd}$ & $\mathrm{Tl}$ \\
\hline $\operatorname{Pr}$ & $55 \%$ & $0 \%$ & $80 \%$ & $15 \%$ & $0 \%$ & $16 \%$ & $0 \%$ & $60 \%$ & $90 \%$ & $90 \%$ \\
\hline $\mathrm{MI} \pm 1 \mathrm{SD}$ & $2.5 \pm 2.5$ & - & $3 \pm 3$ & $1.6 \pm 1.5$ & - & $1 \pm 0$ & - & $64.5 \pm 85.8$ & $17.8 \pm 16.2$ & $60.8 \pm 80.4$ \\
\hline
\end{tabular}




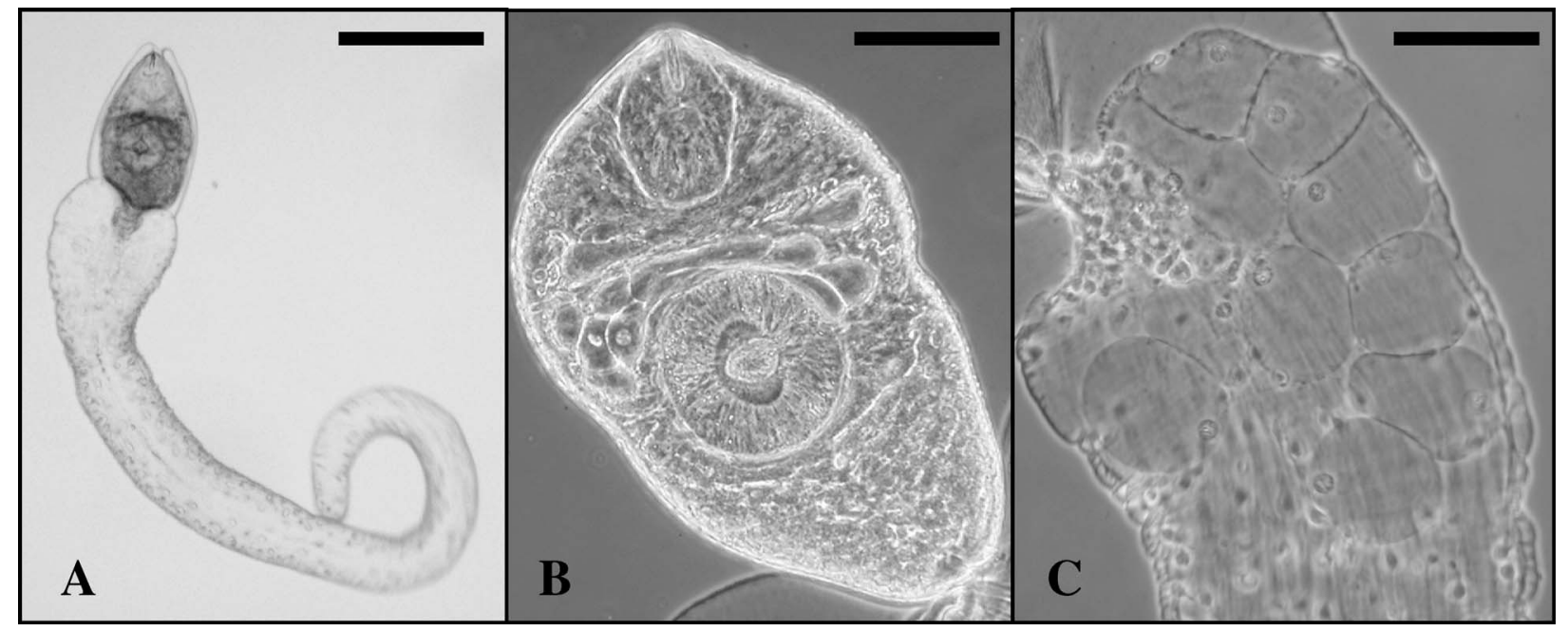

FIGURE 3. Gorgoderid cercaria from $P$. compressum. (A) Entire cercaria. Scale bar $=0.25 \mathrm{~mm}$. (B) Cercaria body; note the stylet and penetration glands. Scale bar $=50 \mu \mathrm{m}$. (C) Anterior portion of tail showing spherical cells. Bar $=50 \mu \mathrm{m}$.

cercariae on the skin or tissues and/or juvenile worms in the kidneys were found in any of the frogs sampled from these 3 sites. Of the 3 adult bullfrogs sampled from Elk Creek, all 3 $(100 \%)$ were infected with adult worms in the urinary bladder (mean abundance $10.6 \pm 14.2$; range $1-27$ ); and 8 of $53(15 \%)$ bullfrog tadpoles (Gosner stage 28-41) were infected with nongravid juveniles, identified as Gorgoderina sp. in the kidneys (mean abundance $0.17 \pm 0.4$ : range $0-2$ ). Worms in the kidneys of tadpoles were $723 \pm 64 \mu \mathrm{m}$ (range 650-770) in length and $147 \pm 25 \mu \mathrm{m}$ (range 120-170) in width and morphologically resembled gorgoderids recovered from the kidneys of tadpoles of northern leopard frogs and Woodhouse's toads from Cedar Creek. No gorgoderid metacercariae were found in the skin, musculature, and viscera of any of the tadpoles or bullfrogs sampled from Elk Creek.

\section{Specimen collection for molecular characterization}

Sequence difference in ITS rDNA among $G$. attenuata, $G$. simplex, Gorgoderina sp., and G. amplicava collected from $\mathrm{Ne}-$ braska, New York, and Wisconsin ranged from 7.0 to $7.6 \%$ and $0 \%$ among Gorgoderina sp. (juvenile worms from the kidneys of a tadpole and toad) and populations of G. attenuata from western Nebraska and New York (Table III). Two specimens of G. attenuata collected from 2 different naturally infected northern leopard frogs and 1 Woodhouse's toad and a single juvenile Gorgoderina sp. worm from the kidneys of an experimentally infected Woodhouse's toad with a laboratory-reared metacercariae had no sequence variation across 849 overlapping bases, whereas a single juvenile Gorgoderina sp. from the kidneys of a leopard frog tadpole contained a single base indel in the ITS 2 region of rDNA. The single gravid $G$. attenuata recovered from a green frog from New York was identical in ITS sequence to all $G$. attenuata from northern leopard frogs and the Gorgoderina sp. from the experimentally infected toad from western Nebraska, except for a 3-base indel (GTT) in the ITS 2 region of rDNA.

\section{Morphological studies for comparisons to the original life cycle study on G. attenuata by Rankin (1939)}

Rankin (1939) did not give any measurements of adult worms from his experimental infections and did not deposit any voucher specimens; however, measurements taken from his figure of an adult worm from a field-collected and laboratoryinfected eastern newt (Notophtalmus virdescens; body length = $5.296 \mathrm{~mm}$; forebody length $=0.926 \mathrm{~mm}$; forebody width $=$ $0.822 \mathrm{~mm}$; hindbody length $=3.962 \mathrm{~mm}$; hindbody width $=$ $1.037 \mathrm{~mm}$; oral sucker length $=519 \mu \mathrm{m}$; oral sucker width $=$ $441 \mu \mathrm{m}$; esophagus length $=89 \mu \mathrm{m}$; esophagus width $=37$ $\mu \mathrm{m}$; ceca ending at $2.1 \%$ of body length; acetabulum length $=$ $740 \mu \mathrm{m}$; acetabulum width $=759 \mu \mathrm{m}$; oral sucker/acetabulum width ratio $=0.58$; ratio of body width to acetabulum width $=$ 2.59; anterior testis length $=556 \mu \mathrm{m}$; anterior testis width $=$ $500 \mu \mathrm{m}$; posterior testis length $=667 \mu \mathrm{m}$; posterior testis width $=389 \mu \mathrm{m}$; seminal vesicle length $=333 \mu \mathrm{m}$; seminal vesicle width $=167 \mu \mathrm{m}$; ovary length $=389 \mu \mathrm{m}$; ovary width $=333$ $\mu \mathrm{m}$; vitellaria with 3 lobes; see Fig. 6) fell in the range of our worms redescribed by Bolek et al. (2009) except for forebody width, hindbody width, ceca ending at percentage of body length, ratio of body width to acetabulum width, anterior testis width, and seminal vesicle length.

Our morphological comparisons of the gorgoderid cercariae of $G$. attenuata from Nebraska pea clams and non-gravid worms from the kidneys of tadpoles and metamorphosed anurans also differed from the original description of these life stages by Rankin (1939; see Fig. 6). Average total length and body length of 10 motile cercariae from our study was 1.108 $\pm 0.084 \mathrm{~mm}$ (range $=1.05-1.27$ ) for total length and $0.218 \pm$ $0.01 \mathrm{~mm}(0.2-0.23)$ for cercaria body length. Rankin (1939) gave a range for total length of his non-motile $G$. attenuata cercariae from naturally and experimentally infected Herrington's fingernail clam (Sphaerium occidentale) as 8.75-9.63 mm and the average size for the cercaria body as $0.41 \mathrm{~mm}$. Rankin's juvenile worm removed from the intestine of a newt was 1.1 $\mathrm{mm}$ in length and $0.27 \mathrm{~mm}$ wide and contained 9 testes, which 

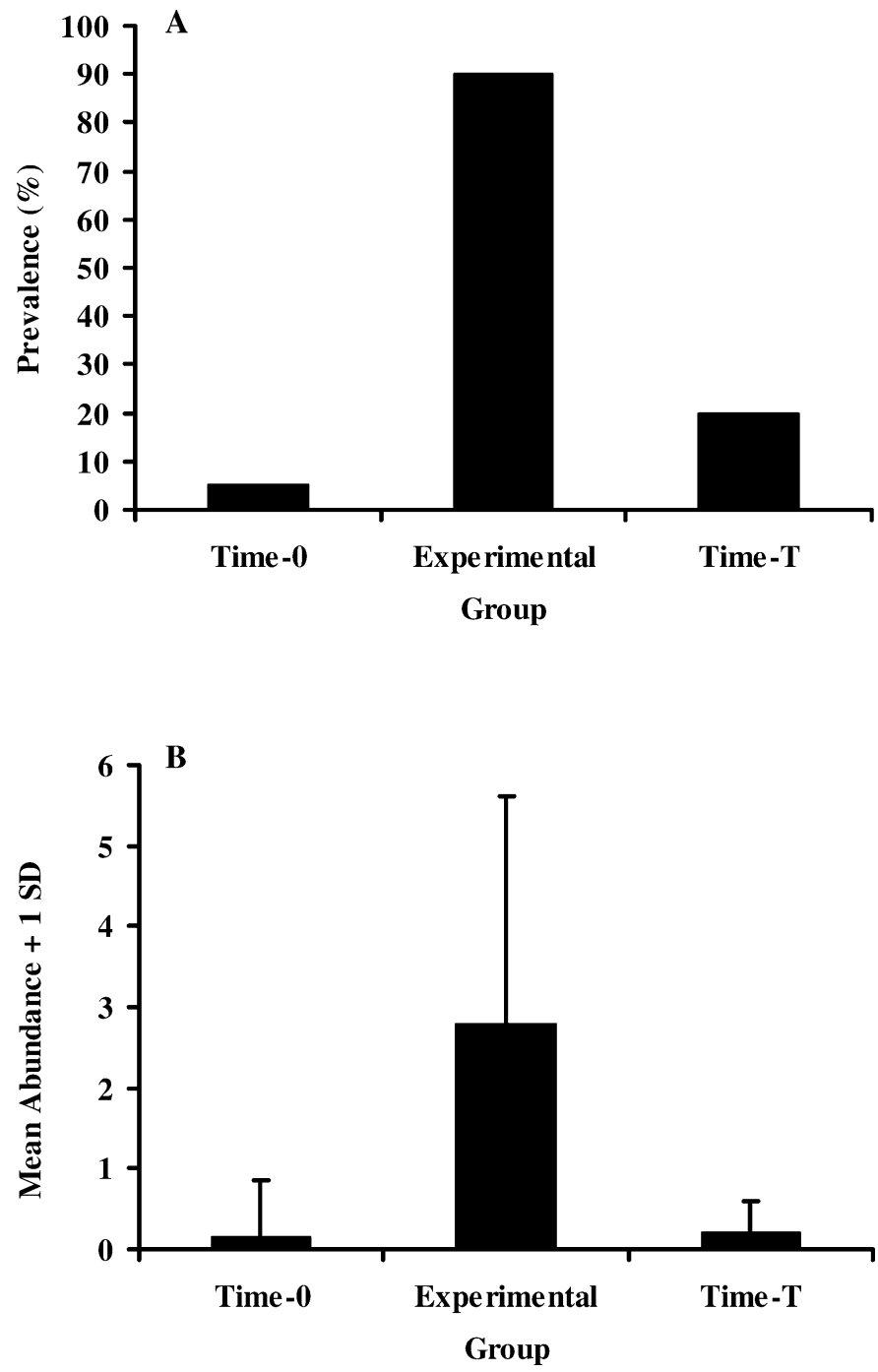

Figure 4. (A) Prevalence and (B) mean abundance of G. attenuata in time-0, experimentally infected northern leopard frog tadpoles, and time-T controls collected from Cedar Creek. $\chi^{2}=23.57, P<0.001$; Kruskal-Wallis test, $H$ corrected $=23.65, P<0.001$.

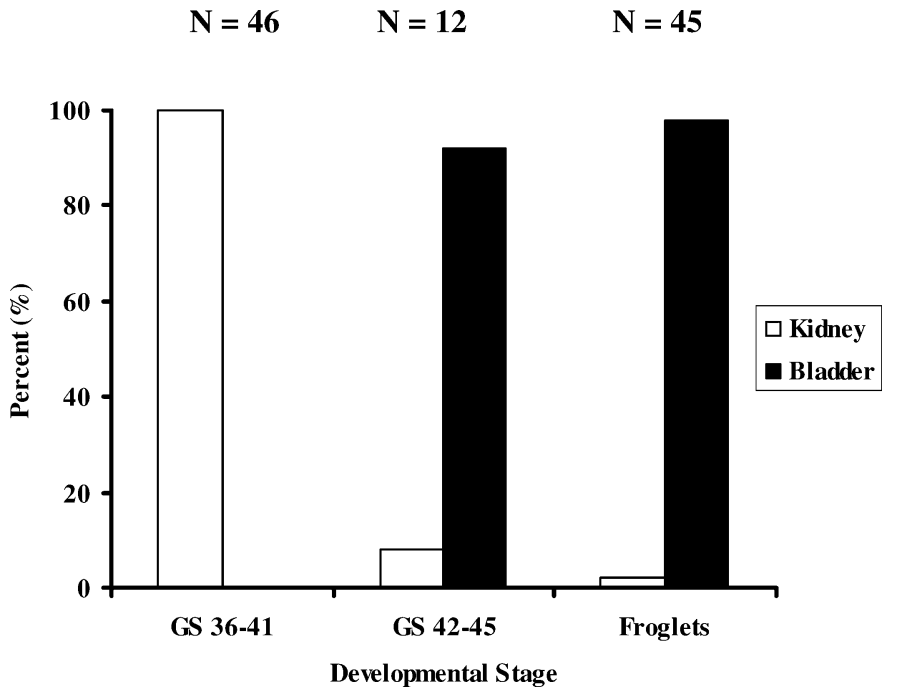

FIGURE 5. Percentage of Gorgoderina sp. recovered from the kidneys and G. attenuata from the urinary bladder of prometamorphic tadpoles, metamorphic tadpoles, and froglets of the northern leopard frog collected form Cedar Creek. $\mathrm{N}=$ number of worms recovered per northern leopard frog developmental stage.

he indicated were in the process of fusing. None of our worms recovered from the kidneys of naturally and experimentally infected tadpoles and frogs of 3 species reached this size $(514 \pm$ $167 \mu \mathrm{m}$, range 330-840), and we never observed 9 testes in any stage of $G$. attenuata from Nebraska tadpoles or frogs (Fig. 6).

\section{DISCUSSION}

The major contribution of our paper is the elucidation of different avenues for, and constraints on, the transmission of a single species of trematode to 3 anuran species. Our field and laboratory studies on the recruitment and development of $G$. attenuata in tadpoles and newly metamorphosed leopard frogs and toads, and the use of molecular techniques to match life cycle stages, indicates that this life cycle is truncated; metamorphosed anurans become infected with $G$. attenuata during the tadpole stage, and worms mature after tadpole metamorphosis. Molecular data from the present study support the conclusion that juveniles of Gorgoderina sp. in the kidneys of leop-

TABLE III. Pairwise genetic distance between ITS genotypes of different populations and stages of Gorgoderina sp., G. attenuata, G. simplex, and G. amplicava. Uncorrected p-distances are expressed as percentages in the lower portion of the matrix. Standard error estimates are based on bootstrap analysis with 1,000 pseudoreplicates and are given in the upper portion of the matrix.

\begin{tabular}{|c|c|c|c|c|c|c|c|c|}
\hline & $\begin{array}{c}G . \\
\text { attenuata } \\
\text { RP1WNE }\end{array}$ & $\begin{array}{c}G . \\
\text { attenuata } \\
\text { RP2WNE }\end{array}$ & $\begin{array}{c}\text { Juvenile } \\
\text { Gorgoderina } \\
\text { sp. RP3WNE }\end{array}$ & $\begin{array}{c}\text { Juvenile } \\
\text { Gorgoderina } \\
\text { sp. BWEXCC }\end{array}$ & $\begin{array}{c}G . \\
\text { attenuata } \\
\text { BWWNE }\end{array}$ & $\begin{array}{c}G . \\
\text { attenuata } \\
\text { RCLNY }\end{array}$ & $\begin{array}{c}G . \\
\text { amplicava } \\
\text { RCWI }\end{array}$ & $\begin{array}{c}G . \\
\text { simplex } \\
\text { RCLWI }\end{array}$ \\
\hline G. attenuata $\mathrm{RP} 2 \mathrm{WNE}$ & 0.0 & - & 0.000 & 0.000 & 0.000 & 0.000 & 0.009 & 0.008 \\
\hline Juvenile Gorgoderina sp. RP3WNE & 0.0 & 0.0 & - & 0.000 & 0.000 & 0.000 & 0.009 & 0.008 \\
\hline Juvenile Gorgoderina sp. BWEXCC & 0.0 & 0.0 & 0.0 & - & 0.000 & 0.000 & 0.009 & 0.008 \\
\hline G. amplicava RCWI & 7.6 & 7.6 & 7.6 & 7.6 & 7.6 & 7.6 & - & 0.008 \\
\hline G. simplex RCLWI & 7.0 & 7.0 & 7.0 & 7.0 & 7.0 & 7.0 & 7.5 & - \\
\hline
\end{tabular}




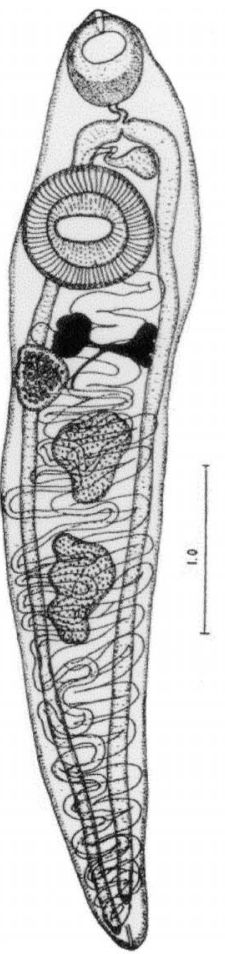

A

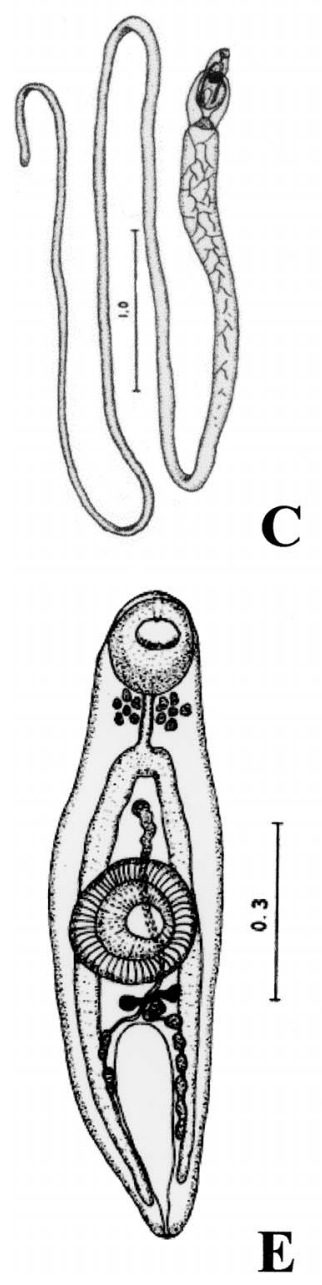

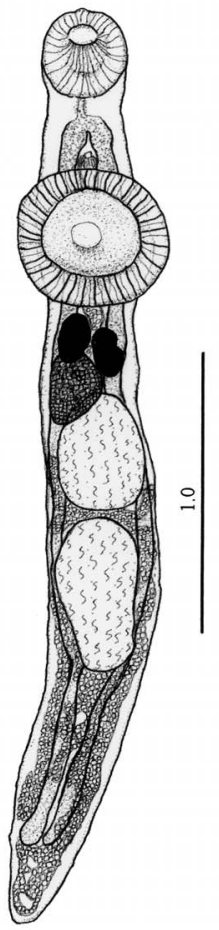

B

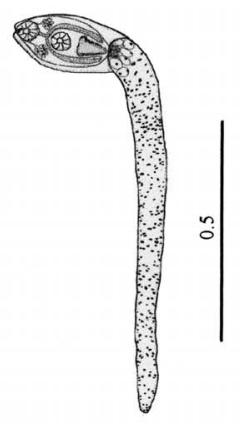

D

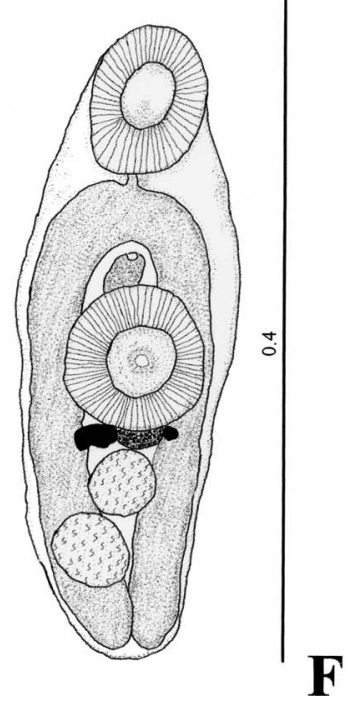

ard frog tadpoles and experimentally infected Woodhouse's toads are conspecific with adult $G$. attenuata from the urinary bladder of northern leopard frogs, Woodhouse's toads, and green frogs from Nebraska and New York. Juvenile and adult G. attenuata did not differ by any base pair of the ITS rDNA across a gapped sequence length of 849 bp (Table III). This contrasts with sequence differences among G. simplex or $G$. amplicava, which differed from individuals of G. attenuata in 59 and $62-63 \mathrm{bp}$, respectively, across a gapped sequence length of 849 bp (Table III).

Our laboratory infections and field data from northern leopard frogs and Woodhouse's toads also showed that worms did not migrate to the bladder and reach sexual maturity until anuran tadpoles metamorphosed into froglets. Studies of anuran metamorphosis indicate that in tadpoles the urinary bladder originates during late prometamorphosis and then increases in developmental rate at the beginning of metamorphic climax, with a fully developed urinary bladder being present in metamorphosed froglets (Viertel and Richter, 1999). Prometamorphic tadpoles (Gosner stage 36-41) did not possess a urinary bladder until the metamorphic stage (Gosner stage 42-45), and this was the developmental stage in which we observed worms migrating from the kidneys into the bladder, indicating that the absence or presence of a bladder is a constraint on worm maturation in different life stages of anurans.

Our field data also indicate that there was a significant difference in the prevalence, mean abundance, and degree of maturation of G. attenuata between tadpoles and metamorphs of northern leopard frogs and Woodhouse's toads, and bullfrog tadpoles and metamorphs. Only 1 metamorphosed northern leopard frog and none of the metamorphosed toads had worms in the kidneys. The lack of worms in the kidneys of metamorphosed leopard frogs and toads indicates that both of these anurans acquire infections with $G$. attenuata primarily during the tadpole stage, and that worms migrate from the kidneys to the urinary bladder as soon as tadpoles metamorphose into froglets or toadlets. In contrast, tadpoles of bullfrogs from Breen's Flyway and Elk Creek were never, or less commonly, infected with gorgoderids in the kidneys than metamorphosed bullfrogs from these locations, indicating that metamorphosed bullfrogs were actively recruiting G. attenuata after metamorphosis. Our laboratory infections of the single toad and 2 bullfrogs with $G$. attenuata metacercariae from damselflies or juvenile worms in the kidneys of tadpoles and the ability of adult bullfrogs and leopard frogs to ingest tadpoles and toads gives additional support that bullfrogs and potentially other anurans recruit $G$. attenuata by feeding on odonates or other anurans. These observations indicate that the life cycle of $G$. attenuata can alternate

FIGURE 6. Line drawings of gravid worms, cercariae, and non-gravid juvenile worms of G. attenuata from Rankin's (1939) original life cycle description, adult redescription by Bolek et al. (2009), and our life cycle study from Nebraska. (A) Gravid adult worm from Rankin (1939). (B) Gravid adult worm from naturally infected $R$. pipiens from Nebraska by Bolek et al. (2009). (C) Cercaria from Rankin (1939). (D) Cercaria from P. compressum from Nebraska. (E) Non-gravid juvenile worm from the intestine of newt from Rankin (1939). (F) Non-gravid 5-day-old juvenile worm from the kidneys of an experimentally infected tadpole of a northern leopard frog. All scale bars in mm. 
between a 2- or 3-host life cycle depending on cercaria/host encounter.

All other North American amphibian gorgoderids for which life cycles are known have a metacercaria stage, which suggests that a 3-host life cycle is the ancestral condition in amphibian gorgoderids (Krull, 1935; Rankin, 1939; Goodchild, 1943, 1948, 1950; Ubelaker and Olsen, 1972). However, there are exceptions to the 3-host life cycle in this family of trematodes, with at least 1 other amphibian bladder fluke exhibiting an alternative 2- or 3-host life cycle. Gorgoderina bufonis a bladder fluke of boreal toads (Bufo boreas) infects dragonflies as the second intermediate host in its life cycle; toads become infected when they ingest the encysted metacercaria in dragonflies. However, the metacercaria of this species can also become progenetic in dragonflies, and apparently eggs are released when dragonflies die in an aquatic habitat (Ubelaker and Olsen, 1972). These observations of alternative 2- or 3-host life cycle strategies of $G$. bufonis and $G$. attenuata suggest that anuran gape size, different life stages of anurans (tadpoles and metamorphs), as well as different species of anurans that vary in their habitats (aquatic, semi-terrestrial, or terrestrial) present different avenues for, and constraints on, transmission of bladder flukes to their respective hosts.

When the results of our current study are compared to the original life cycle study of Rankin (1939), questions arise regarding the possibility of regional variation in the life cycle of G. attenuata. Rankin (1939) in his elucidation of the life cycle of G. attenuata from Massachusetts showed that it used Herrington's fingernail clam ( $S$. occidentale) as the first intermediate host, and metacercariae developed in larval amphibians (anurans and caudatans) and less often in aquatic snails when they ingested the non-motile cercariae; frogs became infected when they fed on infected amphibians or snails.

Because Rankin (1939) did not deposit voucher specimens of his material and based on other inconsistencies in Rankin's life cycle study, questions arise as to the identity of the species of bladder fluke(s) on which he was working. In his experimental infections, he used laboratory-reared tadpoles and metamorphosed green frogs and northern leopard frogs as well as field-collected eastern newts for his infections. He infected laboratory-reared tadpoles by exposing them to cercariae from naturally infected fingernail clams and dissected metacercariae from these second intermediate hosts. He placed these metacercariae (cysts) in fingerbowls, each containing a laboratoryreared green frog or a field-collected newt, and he stated that all frogs and newts acquired cysts and became infected with immature worms. These hosts were then killed at intervals to determine the path of migration. Because frogs and newts feed on moving prey, it is unclear how these amphibians could ingest non-motile $0.1-0.5 \mathrm{~mm}$ metacercariae on the bottom of fingerbowls. He then infected laboratory-reared frogs and field-collected newts by feeding them laboratory-infected tadpoles containing metacercariae, recovered adult worms from these hosts, and infected laboratory-reared fingernail clams to complete the life cycle.

Rankin's original identifications of the cercaria and metacercaria stages of $G$. attenuata were based on his assertion that $G$. amplicava was not present in Massachusetts and differences in the life cycle of the 2 species. However, at the time of his study, the life cycle of $G$. amplicava was only partially known. Krull
(1935) showed that G. amplicava used Sphaerium (Musculium) partumeium, as the first intermediate hosts and aquatic snails as the second intermediate host; adult anurans became infected when they fed on infected snails. However, subsequent studies on the life cycle of G. amplicava by Goodchild (1948) indicated that this species was present in Massachusetts, and that both tadpoles and aquatic snails served as second intermediate hosts when they ingested the non-motile cercariae. In fact, Rankin (1939) and others (Goodchild, 1948; Coil, 1954) indicated that their cercariae of $G$. attenuata looked identical to the cercariae of $G$. amplicava. He distinguished the 2 based on size, with $G$. amplicava having a smaller cercaria $(4.4-7.5 \mathrm{~mm})$ than his $G$. attenuata $(8.75-9.63 \mathrm{~mm})$. Goodchild (1948) in a later study showed that the cercariae of G. amplicava could be as large as 12-17.4 mm, which suggests that Rankin may have been dealing with the cercariae of $G$. amplicava. Other inconsistencies in Rankin's study include the finding of immature worms in the process of fusing testes from 9 to 2 in the intestine of a fieldcollected and laboratory-infected newt. To our knowledge, $G$. attenuata is the only species in the genus from Europe and North America that has been reported to have 9 testes in the metacercaria stage, whereas all Gorgodera species for which life cycles are known have 9 testes in the metacercaria stage (see Dale, 1967; Ubelaker and Olsen, 1972; Prudhoe and Bray, 1982). Rankin's description of the metacercaria is also remarkably similar in size and number of testes to the description of G. amplicava metacercaria by Krull (1935) and Goodchild (1948) (see Fig. 7). Unfortunately, the only record of an adult in Rankin's study is his drawing of a worm recovered from the bladder of a field-collected and laboratory-exposed newt. Rankin (1939) stated that he fixed his specimens under cover slip pressure, and, therefore, he probably distorted his specimens, which more closely resemble G. simplex or Gorgoderina intermedia than our $G$. attenuata recovered from 6 different species of amphibians.

Although other European species of Gorgoderina have been reported to form metacercaria stages in tadpoles (Lees, 1953), few field studies exist on gorgoderid metacercariae in the tissue or skin of amphibians in North America; all these reports are from the eastern part of the United States and Canada, and other amphibian gorgoderid species ( $G$. amplicava and G. simplex), along with $G$. attenuata, were present in bullfrogs and/or green frogs at these locations (Rankin, 1937; Goodchild, 1948; McAlpine and Burt, 1998; Muzzall et al., 2001, 2003; King et al., 2007; K. King, pers. comm.). In contrast, Fortner (1923) examined a large number of northern leopard frogs and green frogs from the Douglas Lake region of Michigan during 19171919 and indicated that bullfrogs were not present at his locations. Like us, he recovered only G. attenuata from these hosts, with prevalences ranging from 38 to $66 \%$. Importantly, in a later study Goodchild (1950) reported examining a serially sectioned metamorphic northern leopard frog tadpole from the Douglas Lake regions that contained numerous juvenile Gorgoderina sp. located in the tadpole's cloaca, urinary bladder, Wolffian ducts, and mesonephric tissue (Fig. 7). Remarkably, Goodchild's drawing looks similar in size and number of testes to our worms recovered from tadpole kidneys from Nebraska, which suggests that the alternative 2-host life cycle also occurs in other parts of the United States. We suggest that to resolve this dilemma, the life cycle of $G$. attenuata from the eastern 

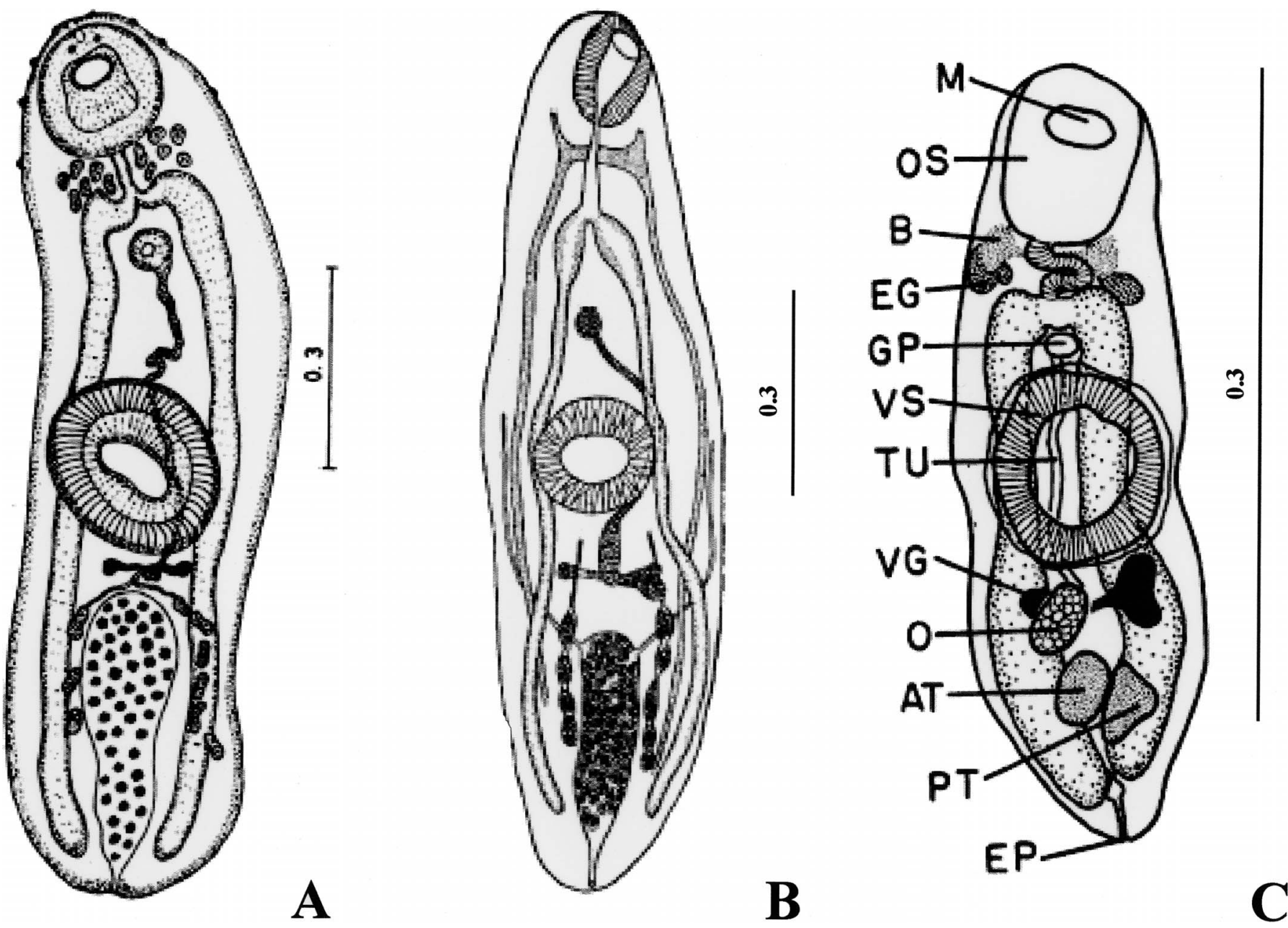

FIGURE 7. Original line drawing of the metacercaria stages of G. attenuata, G. amplicava, and juvenile Gorgoderina sp. published by Rankin (1939) and Goodchild $(1948,1950)$. (A) Line drawings of a metacercaria stage of $G$. attenuata recovered from the tissue of a tadpole from Rankin's (1939) original life cycle description. (B) Line drawing of a metacercaria stage of G. amplicava from the tissue of a tadpole from Goodchild's (1948) original life cycle description. (C) Line drawing of a non-gravid Gorgoderina sp. from the kidney of a naturally infected northern leopard frog tadpole from Michigan by Goodchild (1950). All scale bars in mm.

United States must be reevaluated, or the life cycle stages (cercaria and metacercaria stages) will require comparative DNA sequence analysis across the range of this parasite and across ontogenetic stages.

Although life cycle strategies of amphibian parasites are critical for our interpretations of parasite community structure and life cycle evolution, few recent studies exist on this topic (see Snyder and Janovy, 1994, 1996; Bolek and Janovy, 2007a, 2007b, 2008). Among the North American amphibian bladder flukes, the last life cycle study was resolved over $35 \mathrm{yr}$ ago (Ubelaker and Olsen, 1972). It is remarkable that, although pioneering in their efforts, no one has questioned these life cycle studies, particularly when recent findings on the natural history of salamanders, toads, and other newly metamorphosed anurans indicate that these animals rarely feed on dragonflies and other anurans (Crawford, 1940; Lannoo, 2005; Bolek and Janovy, 2007a). Although difficult to complete, life cycle studies are now more easily conducted by matching adult parasite to larval stages in intermediate hosts using molecular techniques, and we urge other parasitologists to reexamine the life cycles of some of these parasites and examine the larval stages of anurans for their parasites. Only then will we have a better understanding of the selective pressures on the avenues for, and constraints upon, trematode life cycle transmission in anuran hosts.

\section{ACKNOWLEDGMENTS}

The authors greatly acknowledge Dr. Agustín Jiménez-Ruiz, Harold W. Manter Laboratory of Parasitology, University of Nebraska State Museum, for providing specimens of gorgoderids for comparisons. Additionally, we thank the Journal of Parasitology and the American Midland Naturalist for permission to reproduce figures by Rankin, Goodchild, and Bolek, Snyder, and Janovy. M.G.B. thanks Melissa Bolek for help in collecting tadpoles, metamorphosed anurans, and invertebrates, Randy Peterson, Duane Dunwoody, Bill Breen, the Sillisen family, and Dr. Susan Lewis, Carroll College, for access to field sites, Dr. Brent Nickol, University of Nebraska-Lincoln for the use of his animal room, and Cedar Point Biological Station for providing facilities. Additionally, M.G.B. thanks Miloslav Jirků and Chris Whipps for comments on the manuscript and molecular sequences. This work was supported by grants from the Center for Great Plains Studies graduate student grantin-aid, University of Nebraska-Lincoln, Initiative for Ecology and Evolutionary Analysis, University of Nebraska-Lincoln, and the School of Biological Sciences, University of Nebraska-Lincoln. 


\section{LITERATURE CITED}

BoleK, M. G., AND J. R. Coggins. 2000. Seasonal occurrence and community structure of helminth parasites from the eastern American toad, Bufo americanus americanus, from southeastern Wisconsin, U.S.A. Comparative Parasitology 67: 202-209.

, AND - 2001. Seasonal occurrence and community structure of helminth parasites from the green frog, Rana clamitans melanota, from southeastern Wisconsin, U.S.A. Comparative Parasitology 68: 164-172.

, AND —. 2003. Helminth community structure of sympatric eastern American toad, Bufo americanus americanus, northern leopard frog, Rana pipiens, and blue-spotted salamander, Ambystoma laterale, from southeastern Wisconsin. Journal of Parasitology 89: 673-680.

, AND J. JANOVY, JR. 2007a. Small frogs get their worms first: The role of non-odonate arthropods in the recruitment of Haematoloechus coloradensis and Haematoloechus complexus in newly metamorphosed northern leopard frogs, Rana pipiens, and Woodhouse's toads, Bufo woodhousii. Journal of Parasitology 93: 300312.

, AND - 2007b. Evolutionary avenues for and constraints on the transmission of frog lung flukes (Haematoloechus spp.) in dragonfly second intermediate hosts. Journal of Parasitology 93: 593-607.

- AND —. 2008. Alternative life cycle strategies of Megalodiscus temperatus in tadpoles and metamorphosed anurans. Parasite 15: 396-401.

- S. D. SNyder, AND J. JANOvy, JR. 2009. Redescription of the bladder fluke Gorgoderina attenuata from the northern leopard frog, Rana pipeins. Journal of Parasitology 95: 665-668.

Borror, D. J., C. A. TRIPLEhorn, AND N. F. Johnson. 1989. An introduction to the study of insects. 6th ed. Harcourt Brace College Publishers, Philadelphia, Pennsylvania, $875 \mathrm{p}$.

Brooks, D. L. 1976. Parasites of amphibians of the Great Plains: Part 2. Platyhelminths of amphibians in Nebraska. Bulletin of the University of Nebraska State Museum 10: 65-92.

CoIL, W. H. 1954. Contributions to the life cycle of gorgoderid trematodes. American Midland Naturalist 52: 481-500.

CoRT, W. W. 1912. North American frog bladder flukes. Transactions of the American Microscopical Society 31: 151-168.

CRAWFORD, W. W. 1940. The life history of a gorgoderid trematode, presumably of the genus Phyllodistomum. Journal of Parasitology 26(Suppl. 6): 38.

Dale, P. J. 1967. The life cycle of Gorgodera australiensis Johnson, 1912. Tuatara 15: 90-98.

ForTNER, H. C. 1923. The distribution of frog parasites of the Douglas lake region, Michigan. Transactions of the American Microscopical Society 42: 79-90.

Goodchild, C. G. 1943. The life-history of Phyllodistomum solidum Rankin, 1937, with observations on the morphology, development and taxonomy of the Gorgoderinae (Trematoda). Biological Bulletin 84: 59-96.

. 1948. Additional observations on the life history of Gorgodera amplicava Looss, 1899 (Trematoda: Gorgoderidae). Journal of Parasitology 34: 407-427.

. 1950. Establishment and pathology of gorgoderid infections in anuran kidneys. Journal of Parasitology 36: 439-446.

Gosner, K. L. 1960. A simplified table for staging anuran embryos and larvae with notes on identifications. Herpetologica 16: 183-190.

GrabDA-KAZUBSKA, B. 1976. Abbreviation of the life cycles in plagiorchid trematodes. General remarks. Acta Parasitolgoica Polonica 24: $125-141$.

HALl, T. A. 1999. Bio Edit: A user-friendly biological sequence alignment editor and analysis program for Windows 95/98/NT. Nucleic Acid Symposium Series 41: 95-98.

Helt, J., J. Janovy, JR., AND J. Ubelaker. 2003. Phyllodistomum funduli n. sp. (Trematoda: Gorgoderidae) from Fundulus sciadicus Cope from Cedar Creek in western Nebraska. Journal of Parasitology 89: 346-350.

HoAR, W. S., AND C. P. Hickman, JR. 1967. A laboratory companion for general and comparative physiology. Prentice-Hall, Englewood Cliffs, New Jersey, 296 p.
Holl, F. J. 1928. New trematodes from the newt Triturus viridescens. Journal of Helminthology 6: 175-182

King, K. C., J. D. Mclaughlin, A. D. Gendron, B. D. Pauli, I. Giroux, B. Rondeau, M. Boily, P. Juneau, and D. J. Marcogliese. 2007. Impacts of agriculture on the parasite communities of northern leopard frogs (Rana pipiens) in southern Quebec, Canada. Parasitology 134: 2063-2080.

KRULL, W. H. 1935. Studies on the life history of a frog bladder fluke, Gorgodera amplicava Looss, 1899. Papers of the Michigan Academy of Sciences Arts and Letters 20: 697-710.

Kumar, S., K. Tamura, And M. NeI. 2004. MEGA3: Integrated software for molecular evolutionary genetics analysis and sequence alignment. Briefings in Bioinformatics 5: 150-163.

Lannoo, M. 2005. Amphibian declines. The conservation status of United States species. University of California Press, Berkeley, California, 1,094 p.

LEES, E. 1953. Life-history of Gorgoderina vitelliloba (Olsson). Nature 171: 485.

MCAlpine, D. F., AND M. D. B. BuRT. 1998. Helminths of bullfrogs, Rana catesbeiana, green frogs, $R$. clamitans, and leopard frogs, $R$. pipiens, in New Brunswick, Canada. Canadian Field Naturalist 112: $50-68$.

McDiarmid, R. W., AND R. Altig. 1999. The biology of anuran larvae. University of Chicago Press, Chicago, Illinois, $444 \mathrm{p}$.

Merritt, L. W., and K. W. Cummins. 1996. An introduction to the aquatic insects of North America. 3rd ed. Kendall/Hunt Publishing Company, Dubuque, Iowa, $862 \mathrm{p}$.

Muzzall, P. M., M. G. Gillilland III, C. S. Summer, and C. J. Mehne. 2001. Helminth communities of green frogs Rana clamitans Latreille, from southwestern Michigan. Journal of Parasitology 87: 962-968.

- J. D. Peterson, and M. G. Gillilland III. 2003. Helminths of Notophthalmus viridescens (Caudata: Salamandridae) from 118th Pond, Michigan, U.S.A. Comparative Parasitology 70: 214 217.

Needham, J. G., M. J. Westfall, and M. L. May. 2000. Dragonflies of North America. Revised ed. Scientific Publishers, Gainesville, Florida, $939 \mathrm{p}$

Olsen, O. W. 1937. A new species of bladder fluke, Gorgoderina tanneri (Gorgoderidae: Trematoda), from Rana pretiosa. Journal of Parasitology 23: 499-503.

Parker, G. A., J. C. Chubb, M. A. Ball, and G. N. Roberts. 2003. Evolution of complex life cycles in helminth parasites. Nature 425: 480-484.

Poulin, R., And T. H. CRiBb. 2002. Trematode life cycles: Short is sweet? Trends in Parasitology 18: 176-183.

Prudhoe, S. O. B. E., AND R. A. BRaY. 1982. Platyhelminth parasites of the amphibia. British Museum (Natural History), Oxford, U.K., $217 \mathrm{p}$.

RANKIN, J. S. 1937. An ecological study of parasites of some North Carolina salamanders. Ecological Monographs 7: 169-269.

- 1939. The life cycle of the frog bladder fluke, Gorgoderina attenuata Stafford, 1902 (Trematoda: Gorgoderidae). American Midland Naturalist 21: 476-488.

SNyder, S. D., AND J. JANOvy, JR. 1994. Second intermediate hostspecificity of Haematoloechus complexus and Haematoloechus medioplexus (Digenea: Haematoloechidae). Journal of Parasitology 80: 1052-1055.

, AND —. 1996. Behavioral basis of second intermediate host specificity among four species of Haematoloechus (Digenea: Haematoloechidae). Journal of Parasitology 82: 94-99.

SOKAL, L. L., AND J. F. Rohlf. 1981. Biometry. 2nd ed. W. H. Freeman, New York, New York, 859 p.

StAFFord, J. 1902. On the American representatives of Distomum cygonides. Zoologische Jahrbücher Abteilung für Systematik Oekologie und Geographie der Tiere 18: 411-424.

Thompson, J. D., T. J. Gibson, F. Plewniak, R. Jeanmougin, and D. G. HIGGINS. 1997. The CLUSTAL_X windows interface: Flexible strategies for multiple sequence alignment aided by quality analysis tools. Nucleic Acids Research 25: 4876-4882.

Thorp, J. H., AND A. P. Covich. 2001. Ecology and classification of North American freshwater invertebrates. 2nd ed. Academic Press, San Diego, California, 1,056 p. 
Ubelaker, J. E. 1967. Studies on the trematode genus Phyllodistomum. Ph.D. Dissertation, Colorado State University, Fort Collins, Colorado, $137 \mathrm{p}$.

-, AND O. W. OlsEn. 1972. Life cycle of Phyllodistomum bufonis (Digenea: Gorgoderidae) from the boreal toad, Bufo boreas. Proceedings of the Helminthological Society of Washington 39: 94-100.

Viertel, B., AND S. Richter. 1999. Anatomy: Viscera and endocrines. In Tadpoles: The biology of anuran larvae, R. W. McDiarmid and
R. Altig (eds.). University of Chicago Press, Chicago, Illinois, p 92-148.

Westfall, M. J., JR., AND M. L. May. 1996. Damselflies of North America. Scientific Publishers, Gainesville, Florida, 649 p.

Yoder, H. R., AND J. R. CogGINS. 2007. Helminth communities in five species of sympatric amphibians from three adjacent ephemeral ponds in southeastern Wisconsin. Journal of Parasitology 93: 755760. 